\title{
DIKTAT
}

\section{SUPEVISI PENDIDIKAN}

( Bahan Ajar Semester IV )

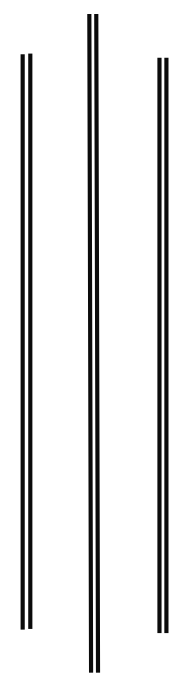

Disusun Oleh

Andi Mujaddidah Alwi, S.Pd., M.Pd

Email: dhidapijarjingga@gmail.com

\section{SEKOLAH TINGGI AGAMA ISLAM DARUD DA'WAH WAL-IRSYAD (STAI-DDI) \\ KOTA MAKASSAR \\ TAHUN 2019}




\section{BAB I \\ PENDAHULUAN}

Supervisi dalam dunia pendidikan menjadi sangat penting dilaksanakan karena berpengaruh terhadap kinerja guru sekaligus pada hasil pembelajaran. Supervisi ini sangat dibutuhkan dalam proses pendidikan dikarenakan ada suatu hal yang mendasari seperti perkembangan kurikulum, dengan berkembangnya kurikulum maka guru-guru dituntut juga ikut berkembang. Kurikulum berkembang sesuai dengan perkembangan zaman, dimana semakin lama zaman semakin canggih oleh karena itu lulusan juga diharapkan mampu mengikuti perkembangan zaman yang salah satu caranya melalui guru. Guru-guru harus mengembangkan kreatifitasnya agar dapat mengikuti perkembangan kurikulum sehingga lulusan yang dihasilkan juga mampu bersaing di dunia pekerjaan.

Untuk meningkatkan kreativitas guru dan pegawai lainnya maka perlu diadakannya supervisi pendidikan. Dimana supervisi ini adalah memberikan bantuan atau binaan kepada guru dan pegawai atau staf lainnya agar dapat memperbaiki kinerjanya dan bekerja lebih baik lagi. Jika kinerja guru dan pegawai atau staf lainnya telah baik maka akan berpengaruh terhadap hasil belajar. Untuk supervisi itu sendiri dapat diartikan sebagai suatu kegiatan yang memberikan binaan atau bantuan yang dilakukan oleh kepala sekolah atau pengawas sekolah terhadap guru dan pegawai serta staf lainnya agar dapat meningkatkan kinerjanya ke arah yang lebih baik.

Salah satu fungsi dari supervisi pendidikan ini adalah meningkatkan kemampuan profesional seperti jika guru dapat bekerja dengan profesional maka akan mempengaruhi proses belajar mengajar ke arah yang lebih baik dan disiplin. Selain itu dengan adanya 
supervisi ini juga akan memperluas pengalaman guru, membuat pembelajaran lebih kreatif dan juga dapat memberikan pengetahuan dan keterampilan terhadap guru.

Sehingga dapat disimpulkan bahwa supervisi pendidikan adalah kegiatan pembinaan yang berupa bimbingan atau tuntunan ke arah perbaikan situasi pendidikan pada umumnya dan peningkatan mutu mengajar dan belajar dan pada khususnya. Dalam pelaksanaannya supervisi pendidikan di sekolah dilaksanakan oleh kepala sekolah yang disebut supervisor, dimana supervisor ini bertugas sebagai pengawas dan pengendali terhadap kinerja guru. Pengawasan dan pengendalian ini dilakukan agar dalam melaksanakan tugasnya guru tidak melakukan penyimpangan sebagai seorang pengajar atau pendidik. Guru dituntut untuk dapat meningkatkan kinerja serta kreativitasnya dalam mengajar, namun untuk meningkatkan atau mengembangkan hal tersebut terdapat beberapa hambatan yang harus dihadapi guru.

Hambatan yang dimaksud yaitu seperti kemampuan guru dalam mengajar, serta sarana dan prasarana yang tersedia. Maka dari itu supervisi ini sangat diperlukan dalam manajemen pendidikan. Sebagai seorang supervisor kepala sekolah harus mampu melakukan berbagai pengawasan dan pengendalian untuk meningkatkan kinerja guru. Hal ini dikarenakan guru memegang peranan penting atau peran utama dari proses pendidikan. Oleh sebab itu supervisi sangat perlu diberikan kepada guru agar kinerja guru menjadi lebih baik lagi sehingga dapat berpengaruh terhadap pendidikan. Karena guru adalah penentu dalam keberhasilan pendidikan maka untuk meningkatkan kualitas atau mutu pendidikan harus dimulai dari guru. 
BAB.II

PEMBAHASAN

\section{A. Pengertian Supervisi Pendidikan}

Di dunia pendidikan di Indonesia istilah supervisi baru dikenal pada tahun 60-an. Dimana Supervisi ini secara etimologis berasal dari bahasa inggris "to supervise" atau mengawasi. Selain itu juga ada beberapa sumber lainnya menyatakan bahwa supervisi berasal dari dua kata, yaitu "super" dan "visi". Dimana super berarti lebih dan visi adalah kemampuan melihat. Dalam dunia pendidikan kepala sekolah digambarkan sebagai seorang "expert" dan "superior", sedangkan guru digambarkan sebagai orang yang memerlukan kepala sekolah. Supervisi dapat diartikan sebagai suatu aktifitas pembinaan yang telah direncanakan untuk membantu para guru dan pegawai serta staf sekolah lainnya dalam melakukan pekerjaan secara efektif sehingga memperoleh hasil yang baik. Manullang (2005) menyatakan bahwa supervisi merupakan suatu proses yang diterapkan terhadap suatu pekerjaan yang telah dilaksanakan bahkan menilai dan mengoreksi pekerjaan tersebut agar sesuai dengan apa yang telah ditetapkan sejak awal.

Supervisi juga dapat diartikan sebagai pelayanan yang diberikan kepada guru agar guru dapat menjadi seorang yang profesional dan dapat melaksanakan dan mengerjakan tugasnya dengan baik terhadap peserta didiknya (Thaib, dkk, 2005). Supervisi merupakan bantuan dari para pemimpin sekolah, yang diberikan dengan maksud untuk perkembangan kepemimpinan dan keprofesionalan guru-guru dan pegawai serta staf sekolah lainnya di dalam mencapai tujuan-tujuan pendidikan. Supervisi merupakan pengawasan terhadap pelaksanaan kegiatan teknis edukatif di sekolah, bukan sekedar pengawasan fisik terhadap fisik material. Supervisi merupakan pengawasan terhadap 
kegiatan akademik yang berupa proses belajar mengajar, pengawasan terhadap guru dalam mengajar dan lainnya.

Pada penerapannya atau pelaksanaannya supervisi tidak hanya mengawasi guru dan pegawai serta staf lainnya, tetapi juga mengawasi apakah pekerjaan yang dilakukan telah berjalan baik dan sesuai ketentuan atau belum, serta juga memberikan solusi dan mencari cara secara bersama dalam memperbaiki pekerjaannya ke arah yang lebih baik dan sesuai dengan ketentuan yang telah ditetapkan. Ada beberapa pendapat para ahli mengenai defenisi dari supervisi pendidikan diantaranya adalah :

1. Adam dan Dickley dalam bukunya "basic principle of supervision", mendefinisikan supervisi adalah suatu program yang berencana untuk memperbaiki pengajaran. Pengajaran yang dimaksud yaitu proses belajar mengajar.

2. Mc Nerney menjelaskan bahwa supervisi adalah suatu langkah yang memberikan arah dan bimbingan dalam proses pengajaran.

3. Burton dan Bruckner, memberikan pandangannya atau pendapatnya mengenai supervisi dimana mereka menjelaskan bahwa supervisi ini merupakan suatu pelayanan yang diberikan kepada guru dalam memperbaiki perkembangan guru.

4. Boardman dalam bukunya "democratic supervision in secondary school" bahwa supervisi merupakan suatu usaha yang mengorganisir, mendorong dan mengarahkan guru-guruyang ada di sekolah agar lebih mengerti dalam menjalankan seluruh fungsi pengajaran baik secara individu maupun secara bersama (Muwahid,2004). Arti atau maksud dari supervisi dalam kaitannya atau hubungannya dengan pendidikan adalah berupa pembinaan yang diberikan kepada guru.

Pada konsep supervisi tradisional menganggap supervisi ini sebagai inspeksi. Kata inspeksi ini sendiri memiliki makna melakukan pemeriksaan terhadap halhal yang telah dilaksanakan guru dan tidak memberikan bimbingan ataupun arahan (Arsyam, M. 
2020, July 4). Sehingga menimbulkan bahkan menyebabkan guru merasa takut dan tidak bebas dalam melaksanakan tugasnya serta juga merasa terancam dan takut untuk bertemu dengan supervisor.

Hal ini dikarenakan pemahaman yang salah tentang supervisi tradisional. Dimana supervisi secara tradisional ini diartikan sebagai seorang supervisor atau seorang pengawas yang mencari kesalahan orang yang disupervisinya sehingga dapat mempengaruhi penilaiannya terhadap orang yang disupervisikannya itu. Orang yang disupervisikan dalam hal ini yaitu guru, sehingga banyak guru yang merasa takut terhadap supervisor dan pengawas (Sahertian, 2000).

\section{B. Tujuan Supervisi Pendidikan}

Segala sesuatu yang di buat tentu memiliki tujuan. Begitu juga dengan supervisi pendidikan yang memiliki beberapa tujuan diantaranya yaitu:

1. Memberikan bantuan kepada guru agar dapat memahami tujuan dari pendidikan yang diberikan di sekolah, selain itu juga memberikan bantuan kepada guru agar tidak hanya berfokus pada bidang studynya tetapi juga harus mengetahui tujuan akhir dari pendidikan.

2. Membantu Guru dalam memahami siswanya serta kebutuhan siswanya. Sehingga menciptakan suasana yang menyenangkan dalam belajar.

3. Membantu guru agar nantinya dapat menjadi seorang pemimpin yang baik yang dapat bekerjasama dan membantu orang lain yang kurang mampu atau yang memerlukan bantuan tanpa harus memaperkan kehebatannya.

4. Membantu menemukan kelebihan yang dimiliki oleh guru dan memberikan tanggung jawab kepada guru tersebut sesuai kemampuannya tanpa harus mencari kelemahannya. 
5. Memberikan motivasi kepada guru agar lebih baik lagi saat tampil di hadapan para siswanya. Jika terdapat kekurangan maka akan diperbaiki secara bersama-sama.

6. Membekali guru-guru baru mengenai tugastugas yang akan diembannya agar dapat dilaksanakan dengan baik.

7. Memberikan bantuan kepada guru dalam menemukan kesulitan dan masalah yang dihadapi siswanya dan mencarikan solusinya (Rifai, 1982).

Selain memberikan peningkatan terhadap keterampilan dan pengetahuan guru, supervisi juga bertujuan memberikan dan meningkatkan motivasi guru. Kepala sekolah sebagai supervisor bertanggung jawab mengawasi proses belajar mengajar di sekolah dengan cara berkunjung ke kelas, selain itu kepala sekolah sebagai supervisor juga memberikan dorongan kepada guru agar selalu mengembangkan kemampuannya dan menerapkan kemampuannya itu dalam proses mengajarnya serta juga memberikan dukungan kepada guru dalam mengerjakan tugas-tugas dan tanggung jawabnya secara sungguh-sungguh (Arsyam, M. 2020).

Supervisi ini akan berhasil jika saling memperhatikan satu dengan yang lainnya tidak hanya memikirkan atau memperhatikan satu hal saja tapi banyak hal. Oleh sebab itu supervisi pendidikan bertujuan memberikan perbaikan dan pengembangan terhadap proses belajar mengajar namun juga memberikan pengembangan terhadap guru dalam banyak hal termasuk disana pengadaan fasilitas sampai dengan pembinaan hubungan baik dengan sesama (Hariwung, 1989). Supervisi memiliki tiga kegunaan yaitu, pertama bagi seorang supervisor, supervisi ini dapat berguna dalam meningkatkan kemampuannya dalam memberikan arahan terhadap supervisinya. Yang kedua. Dengan adanya supervisi ini juga memberikan kegunaan bagi guru yaitu dapat meningkatkan keprofesionalan guru dalam melaksanakan proses pembelajaran. 
Dan yang terakhir supervisi ini berguna dalam memberikan bantuan untuk terciptanya suatu tujuan yang diharapkan. Terdapat tiga prinsip hubungan kemanusiaan yang apabila dilakukan maka supervisi akan mencapai tingkat kegunaannya. Dimana ketiga prinsip itu adalah pengakuan dan penghargaan, objektifitas dan kesejawatan (Risnawati, 2014).

\section{Prinsip Dasar Supervisi}

Dalam pelaksanaannya supervisi dilakukan berdasarkan beberapa prinsipnya. Diantara banyaknya prinsip supervisi menurut Suhertian (2008) supervisi memiliki beberapa prinsip yaitu :

1. Prinsip IImiah (scientific). Dimana berdasarkan prinsip ini supervisi dilaksanakan harus berdasarkan data yang objektif dimana data yang diperoleh harus di dapatkan dengan observasi yang nyata bukan didapatkan hanya dengan cerita belaka saja.

2. Prinsip Demokratis. Dengan prinsip ini supervisi dilakukan harus dengan musyawarah. Jika permasalahannya dengan guru maka guru juga harus dilibatkan agar terciptanya rasa kebersamaan dan kekeluargaan.

3. Prinsip Kerjasama. Dimana prinsip ini memberikan rasa saling berjuang bersama dan tidak menimbulkan sifat yang individual.

4. Prinsip Konstruktif dan Kreatif. Supervisi dapat dilakukan dengan cara yang nyaman dan menyenagkan sehingga mendorong guru agar kreatif dan tidak takut.

Selain ini juga ada prinsip supervisi menurut Gunawan (2002), yaitu :

1. Prinsip Fundamental/dasar. Dimana prinsip ini bersumber pada sesuatu yang kokoh dan mendasar seperti pancasila.

2. Prinsip Praktis. Dalam pelaksanaan supervisi, pada prinsip praktis ini seorang supervisor harus berpedoman pada prinsip positif yaitu prinsip yang harus diikuti dan prinsip negatif yang seharusnya tidak diikuti. 
Dimana prinsip positif dan negatif yang dimaksud adalah :

Prinsip positif supervisor antara lain yaitu ;

a. Supervisi hendaknya mendorong guru dalam mengembangkan kemampuannya.

b. Supervisor dan guru harus saling menghormati.

c. Supervisor harus sabar dan harus memberikan dorongan kepada guru.

d. Supervisi seharusnya dapat mengembangkan potensi dan kelebihan lainnya untuk mencapai kemajuan dan tidak mencari kesalahan.

Prinsip negatif supervisor antara lain yaitu :

a. Supervisi tidak boleh memaksakan kehendaknya kepada orang-orang yang disupervisi serta supervisi juga tidak boleh bersifat otoriter.

b. Supervisi tidak boleh dilakukan untuk mencari-cari kesalahan guru.

c. Supervisi tidak boleh tergesa-gesa mengharapkan hasil dan mendesak bawahan serta seorang supervisor tidak boleh cepat putus asa (Maryono,2011).

\section{Ruang Lingkup Supervisi}

Kegiatan yang paling penting dan paling utama dari supervisi adalah pembinaan dan pengembangan yang diberikan kepada seluruh guru dan pegawai serta staf sekolah lainnya. Untuk mencapai atau memperoleh kualitas pembelajaran yang lebih baik maka sangat perlu dilakukannya supervisi. Jika supervisi dapat terlaksana dengan baik maka akan dapat meningkatkan kualitas pembelajaran di sekolah. Dengan meningkatnya kualitas pembelajaran diharapkan hasil belajar siswa juga ikut meningkat, sehingga untuk lulusan sekolah juga akan meningkat pula.

Menurut Arikunto (2004) lebih rinci la mengidentifikasi sasaran supervisi yang ditinjau dari objek yang akan disupervisi menjadi tiga kategori yaitu :

1. Supervisi Akademik. Supervisi akademik ini lebih menekankan pada masalah akademik atau masalah pembelajaran. Dimana supervisi ini membantu guru dalam 
mengembangkan kemampuannya untuk mengelola pembelajaran dan meningkatkan mutu dari hasil pembelajaran.

2. Supervisi Administrasi. Dimana pada supervisi ini lebih cenderung ke arah administrasi yang membantu terlaksananya pembelajaran dengan baik. Dimana menyangkut sarana dalam pembelajaran atau fasilitas yang harus dipenuhi agar proses belajar mengajar dapat terlaksana dengan baik seperti buku pelajaran, perpustakaan dan lainnya.

3. Supervisi Lembaga. Dimana untuk supervisi lembaga ini dimaksudkan untuk meningkatkan kinerja sekolah dan nama baik sekolah yang akan dapat meningkatkan kualitas sekolah. (Risnawati, 2014). 


\section{BAB III \\ KESIMPULAN}

Berdasarkan uraian diatas, maka dapat diambil simpulan sebagai berikut :

1. Supervisi ialah suatu aktifitas pembinaan yang direncanakan untuk membantu para guru dan pegawai sekolah lainnya dalam melakukan pekerjaan secara efektif dan lebih baik.

2. Orang yang melakukan supervisi disebut supervisor, sasaran supervisi adalah guru dan staf sekolah lainnya.

3. Tujuan supervisi adalah sebagai pengendalian kualitas, pengembangan profesional, dan untuk memotivasi guru.

4. Prinsip dasar dari supervisi adalah prinsip ilmiah, demokratis, kerjasama dan prinsip konstruktif dan kreatif. Selain itu juga ada prinsip fundamental/dasar dan prinsip praktis.

5. Ada tiga kategori supervisi yaitu supervisi akademik, supervisi administrasi dan supervisi lembaga. 


\section{Daftar Pustaka}

Hariwung.1989. Supervisi Pendidikan. Jakarta: Depdikbud.

Maryono. 2011. Dasar-dasar dan Teknik Menjadi Supervisor Pendidikan. Yogyakarta. Ar-ruzz media.

Arsyam, M. (2020). PENGARUH KEMAMPUAN SUPERVISIONAL KEPALA SEKOLAH DAN PERAN KOMITE SEKOLAH TERHADAP KINERJA GURU SMA NEGERI DI KOTA MAKASSAR

Arsyam, M. (2020, July 4). Guru Seabagai Pilar Pembangunan Bangasa. https://doi.org/10.31219/osf.io/r8xy3

Muwahid,S. 2004. Administrasi pendidikan. Jakarta: Bina ilmu.

Purwanto,ngalim.2010.Administrasi dan Supervisi Pendidikan. Bandung: Remaja rosdakarya.

Rifai, moh. 1982. Supervisi Pendidikan. Bandung: Jemmars .

Risnawati. 2011. Administrasi dan Supervisi Pendidikan . Yogyakarta: Aswaja pressindo.

Sahertian. 2000. Konsep Dasar dan Teknik Supervisi Pendidikan dalam Rangka Pengembangan Sumber Daya Manusia . Jakarta: Rineka cipta.

Slameto. 2016. Supervisi Pendidikan oleh Pengawas Sekolah. Jurnal Manajemen Pendidikan. Vol 3 (2), 192-206.

Suhardan, dadang. 2010. Supervisi Profesional. Bandung : Alfabeta.

Suryani,cut. 2015. Implementasi Supervisi Pendidikan dalam Meningkatkan Proses Pembelajaran di MIN Sukadamai kota Banda Aceh. Jurnal Ilmiah Didaktita. Vol 16 (1) , 2342. 
Thaib,dkk. 2005. Standar supervisi pendidikan. Jakarta. Depag RI. 